UNNES

\title{
Analysis of Students' Knowledge Mastery and Oral Communication Skills Through the Implementation of Think-Pair-Share Model
}

\author{
Mustikawati $^{1 \bowtie}$, Sri Mulyani Endang Susilowati ${ }^{1}$, Retno Sri Iswari ${ }^{2}$
}

Biology Department, FMIPA, Universitas Negeri Semarang, Indonesia

\begin{tabular}{|c|c|}
\hline Info Article & Abstract \\
\hline $\begin{array}{l}\text { History Article: } \\
\text { Received: April } 2018 \\
\text { Accepted : Juli } 2018 \\
\text { Published: } \\
\text { Agustus } 2018\end{array}$ & $\begin{array}{l}\text { This research aimed to analyze the effect of Think-Pair-Share (TPS) learning model on knowledge } \\
\text { mastery and oral communication skills of high school students. This study is an experimental quasi- } \\
\text { research with nonequivalent control group design. Population includes all students of class X MIPA } \\
\text { High School } 1 \text { Subah with X MIPA } 1 \text { as experiment class and X MIPA } 2 \text { as control class determined } \\
\text { by purposive sampling. The result of t-test shows the significant difference in average post-test grade } \\
\text { between experiment and control classes. The rise of learning outcome average in the experimental class } \\
\text { is } 0,39 \text { while control class is } 0,18 \text { (low). The t-test result also shows a significant difference grade of oral } \\
\text { communication skill between the experimental and control classes. The average score of oral } \\
\text { communication skill of experiment is } 78.33 \text {, better than control class with } 67.15 \text {. It indicates that the } \\
\text { TPS model had a positive influence on the students' of mastery knowledge and oral communication } \\
\text { skills. This finding is supported by the good responses from students and teacher toward model TPS } \\
\text { implementation in environmental change concept. }\end{array}$ \\
\hline
\end{tabular}

(C) 2018 Universitas Negeri Semarang

Correspondence:

Gedung D6 Lt.1 J1 Raya Sekaran Gunungpati Semarang

E-mail: mustikaw335@gmail.com

p-ISSN 2252-6579

e-ISSN 2540-833X 


\section{INTRODUCTION}

The current curriculum is developed according to $21^{\text {st }}$ centuries learning paradigm which emphasizes students' thinking and learning skills. These skills include problem-solving, critical thinking, collaboration, and communication skills. Communication skills lead to the development of students' thinking capabilities. It will develop if it is clearly and accurately delivered (Tamwil \& Liliasari, 2014). The communication is better learning style than reading, observing, or listening. When someone communicates, information shared, opinion competed, and collaborated to solve a particular problem. In the discussion process, thinking capabilities are more dominant than reading and listening (Abidin, 2014).

The facts found that biology learning was still not appropriate with the characteristic of sciences learning. Biology learning should not be students centered. In SMA N 1 Subah, students are not competent in giving oral ideas, oral questions, making a hypothesis and, making a conclusion from the given statements. Only $21 \%$ of 66 students capable of providing ideas or opinions in the class. Students are lacking active giving opinion in a discussion, asking questions of teachers or classmates during the learning process, and are afraid to speak up in front of the class. Only a few students are courageous in being active and speak up their opinions. Therefore students learning outcomes were less optimal. It was still below the passing grade (KKM) of biology lesson which is 75 .

TPS learning model gives a variation of discussion pattern. TPS learning model allows the students to think individually, talk to each other or with their partner, and share an opinion in a bigger group. Students would have active roles in learning activities (Kusuma \& Aisyah, 2012). TPS could improve students' oral communication skills (Azlina, 2008). Kitaoka (2013) stated that TPS could improve the students' understanding. Students would be active during the learning, bold to speak up their opinions, appreciate each other, and listen to friends about problem discussed. The phase of TPS learning are: (1) Think, students are thinking about the answer to given questions by teacher; (2) Pair, students, are getting paired with another friend to discuss problems using discussion worksheets (LDS) given by teacher; (3) Share, students are presenting the discussion results in front of the class. In this activities, they hopefully will give each other questions and answers, which lead them to construct the understanding integratively, and train their communication skills. Based on Marlina \& Ikhsan (2014), one of the superiority of TPS learning model is that it could raise the student's participation to talk and speak up their ideas in the learning process. The powers of TPS learning model are: gives students more time to think, answer, and help each other, improve their participation and collaboration with partners, facilitate interaction, improve confidence, their ideas shared, and more manageable in the grouping. The implementation of TPS learning model in biology emphasizes students participation to discover their knowledge by doing activities in the paired discussion. Students trained to communicate, bold to speak up their opinions and appreciate the others, so could improve their understanding and study outcome.

In Bahasa Dictionary (2017), mastery means the understanding or capability to use the knowledge and intellectual. Knowledge is something that known correlated to the learning process. So knowledge mastery is students capability to understand the knowledge after learning activities. The knowledge includes the domain of cognitive, which is one of the learning outcome aspects. As in Krathwohl (2002) domain of cognitive in revisioned Bloom taxonomy, are Remember (remember and recognize), Understand (interpret, clarify, classify, summarise, conclude, compare, and explain), Apply (do and implement), Analyze (analyze, distinguish, organize, and connect), Evaluate (evaluate, investigate, and criticize), and Create (plan and create). Giyastutik (2009) found that TPS learning model could improve students' learning outcome of biology. Other research by Fiani \& Yulida. (2015) implementation of TPS learning model proven significantly affect the students' learning outcome. 
Oral communicating is giving information through word or sentence by speaking. In sciences learning, verbal communication usually happens in discussion activities, because at that moment social interaction occurs. Every group member will directly interact with each other. Verbal communication gives clearer results and understanding than the written one (Dirman \& Juarsih, 2014). The indicators of oral communication from student activities include discussion, presenting its findings, giving opinions, answering questions, writing discussion results, correct grammar, brief conversation, clear and quickly understand and also clear voice (Rahayu, 2013). Oral communication aspects that usually happen in discussion activities include giving opinions, responding opinions, asking questions, answering questions (Yusefni \& Sriyati, 2015). Whitehead (2007) stated that TPS could improve oral communication skills because students have more time to discuss their ideas and there are positive change in understanding level, awareness, oral aspects, and attitudes.

In the implementation of TPS learning model especially in environmental change concept, activities of Think could be seen from the question asked by students when the teacher gives pictures and videos. Next step is Pair; it enables students to speak or communicate in the paired discussion. In this step, students discuss the discussion worksheet (LDS) about environmental change given by the teacher. After discussion, they are presenting the results in front of the class (Share). In this step, the emerged ideas from the discussion are shared with the other students.

Based on the given problems, the purpose of this research was to analyze the influence of TPS learning model implementation on the knowledge mastery and oral communication skills of the students. Therefore, research on the analysis of students' knowledge mastery and verbal communication skills through implementation of TPS learning model needs to be conducted.

\section{RESEARCH METHOD}

This study was quasi-experimental research with nonequivalent control group design. The population was all students from class X MIPA of SMAN 1 Subah in academic years 2016/2017, which consisted of four classes. The samples were students class X MIPA 1 as the experimental and XI MIPA 2 as the control, determined by purposive sampling, based on teacher request. Both classes were given a pre-test at the beginning of the learning. TPS learning model applied in experiment class, whereas ordinary discussion applied in control one.

Post-test conducted in both classes at the end of the learning. Data obtained from this research included a score of pre-test and post-test which measured using the instrument of 30 items multiple choice questions and data of oral communication skills students obtained from observation. Data on the post-test grade of experimental and control classes analyzed by t-test to determine the average difference grade of students' knowledge mastery. Next, the pre-test and post-test analyzed by $\mathrm{N}$-gain to determine the rise in average grade from learning the outcome. Oral communication skills also analyzed by t-test to determine the average difference grade of oral communication skills' results. Others include students and teacher responses as supportive data.

\section{RESULT AND DISCUSSION}

This research carried out in SMAN 1 Subah in academic years 2016/2017, the subject of environmental change, results as follows.

\section{Students' Knowledge Mastery Skills}

Assesment of students knowledge mastery skills obtained from post-test. A post-test grade between experimental and control classes analyzed by t-test because of its normal and homogeneous distribution. A t-test analysis uses the significance level of 5\% by application SPSS version 16 with statistic Independent-Sample t-test. The results can be seen in Table 1. 
Table 1 T-test Results of Post-test Grade From Experiment and Control Classes

\begin{tabular}{lll}
\hline & Experiment Class & Control Class \\
\cline { 2 - 3 } Average Post-test Grade & 82.54 & 75.34 \\
Highest Post-test Grade & 93.3 & 93.3 \\
Lowest Post-test Grade & 70.0 & 63.3 \\
Standard of Deviation & 5.60929 & 7.27566 \\
Number of Students & 38 & 40 \\
\hline t table & 1.96 & \\
t calculated & 4.881 & \\
Sig. (2-tailed) & 0.00 & \\
Description & $\mathrm{t}$-calculated $>$ t-table, $\mathrm{H}_{0}$ Rejected \\
& $\mathrm{P} 0.00<0.05, \mathrm{H}_{0}$ Rejected \\
\hline
\end{tabular}

Based on Table 1, students outcome in experimental class has average post-test of 82.54 which is higher than control one, 75.34. The hypothesis of posttest through t-test for both classes with significance 0.05 , the value of $\mathrm{p} 0.00$, which $0.00<0.05$, therefore, Ho rejected. This shows that average posttest grade between experiment and control classes was different. Thus it can be stated that there is a significant difference of learning outcome (knowledge mastery) between experimental class which applied by TPS learning model and control class which applied by common discussion.

Based on N-gain results, average pre-test in the experimental class is 71.76 , and average post-test grade is 82.54 , so the rise of average learning outcome in experiment class as 0.39 or in the moderate criteria. While the average pre-test of control class is 70.25 and average post-test grade is 75.34 , so the rise of average learning outcome in control class as 0.18 or in the low criteria. Both classes have the increase in cognitive learning outcome, but the experimental class is higher compared to the first control class. Besides that, classical passing grade in experiment class better than control one, students in experiment class reached the passing grade (KKM) as much as $92.1 \%$, while control class as much as $52.5 \%$ from total students in the classroom. From three results, shows that there is difference learning outcome between experimental class which used TPS learning model with control class which used discussion learning. This difference arose because there is a different treatment than given in both classes.

Implementation of TPS learning model in the subject of environmental change began with teacher played videos or pictures about environmental change. Students observed the images that played and independently gave a more precise look. Thinking activities are thoughts about problemsolving or questions provided by the teacher. The step of thinking demands students to became keener in studying and active searching references so help them solve the problems or questions given by the teacher. Furthermore, students got paired with their friend who sits next to them, two by two, to discuss problem or questions from discussion worksheets given by the teacher. The step of discussion is a step to deliver students' ideas or opinion and also to unify opinion. Discussion makes students more interest and enthusiasm to follow the lesson. The last step is Share, paired students then presented their discussion results in front of the class. During the learning, the teacher guided students to find the concepts. Accordance with Rusmaryanti (2013) cooperative learning type ThinkPair-Share is one of the models that can be applied in biology lesson as it could determine students' knowledge level. If students think and answer more often, means they have higher knowledge, so that they could interact well and hopefully would increase the learning outcome.

Implementation of TPS learning model trains students thinking skills through steps of thinking, pairing, and sharing. Students search answer based on their minds through reasoning, this result then discussed together with their partner in the step of Pairing, and the result presented in front of the class in step of Sharing. These steps that had been through made their answer became 
tiers, from their mids then united with other students, and in the end, became general conclusion. This paired discussion made the material studied easier because learning goes more effective. As much as $97.4 \%$ of students stated that discussion made them easier to understand the concept of environmental change. The teacher also gave reasons that TPS learning model helped students to understand the subject because of three steps in TPS; students were more active in the learning, they discovered their knowledge, were capable of collaborating with friends to solve problems through discussion and share knowledge with others, so they easily understand the lesson. $2.6 \%$ of students were still hard to understand the concept of environmental change through this TPS learning model. This is because they had no interest in the paired discussion and easier to understand in the other way as each student have different study style.

Paired discussion trains students to collaborate and trains individual responsibility in discussion with their partner. If students have trouble with the fundamental topic in the subject, they can ask their partner before asking the teacher. This is according to students respond as much as $97.4 \%$ students chose to discuss with friends if they had trouble in understanding the lesson. $2.6 \%$ of students still disagree with this. This because the students are reposeful-type, shy, and have trouble with their friends. Learning activities such as discussion make learning more effective so that it could increase the students' learning outcome, in this research is students knowledge. This is in line with Ni'mah \& Dwijanti (2014) who stated that the TPS learning model has proven in increasing students' learning outcome. So the research by Oktavia et al. (2016) stated that TPS learning model influences in learning outcome and could it. Bamiro (2015) and Rahayu \& Pramukantoro (2013) stated that class which applied TPS learning model had higher learning outcome compare to the class which applied a conventional one.

Learning in control class was conducted by a common discussion with a group member of 4-5 students. Just a few students were activated in discussion activities. Most of the group had only 1-2 members from each group, while the rest member was passive/just kept silent so its influence in the lower learning outcome (knowledge mastery) of the students.

In experiment class, little students had cognitive study outcome which not reached the passing grade (KKM). This is because few things such as different understanding level of each student in understanding the subject and the lack of teacher attention during learning caused because too many groups in one class so teacher not yet optimally guide students, especially when the discussion is going. Other things that influence the student study outcome is internal and external to students. As stated by Rumini \& Sundari (2006) that the student study outcome influenced by two factors, internal and external. The internal factor such as motivation, healthy, composure, intelligence, and readiness. External factor such as teacher roles manage the learning process; parent roles educate their children and society.

\section{Oral Communication Skills of Students}

Assesment of the oral communication skills of students conducted by observing it during the discussion that aims to determine the verbal communication of students in discussion gives opinions, asks and answers questions. Each students abilities were evaluated by an observer in the discussion. A grade of oral communication skills between experimental and control classes was analyzed by t-test because of its normal and homogeneous distribution. The t-test was employed with a significance level of $5 \%$ by SPSS version 16 with statistic Independent-Sample $t$-test. The results can be seen in Table 2 .

Table 2 T-Test Results of Oral Communication Skills From Experiment and Control Classes

Experiment Class Control Class




\begin{tabular}{lll}
\cline { 2 - 2 } Average Posttest Grade & 78.33 & 67.15 \\
Highest Posttest Grade & 90.63 & 89.06 \\
Lowest Posttest Grade & 64.06 & 46.88 \\
Standard Deviation & 7.90213 & 1.31127 \\
Number of Students & 38 & 40 \\
\hline T table & 1.96 & \\
T calculated & 4,587 & \\
Sig. (2-tailed) & 0,000 \\
Description & t-calculated $>$ t-table, $\mathrm{H}_{0}$ Rejected \\
& P $0,00<0,05, \mathrm{H}_{0}$ Rejected \\
\hline
\end{tabular}

Based on Table 2. can be seen that the average grade of students' oral communication skills in the experimental class is better than the control one with $\mathrm{p} 0,00<0,05$. Then the, $\mathrm{H}_{0}$ rejected $\left(\mathrm{H}_{0}=\right.$ no difference between oral communication skills experiment class and control class after learning). It shows that the average score of students' oral communication skills between experimental and control class is significantly different, therefore TPS learning model positively affect the oral communication skills of students.

Assesment of oral communication skills used in observation was divided into four ranges of scores. The learning process in the experimental class used TPS learning model with each group consisting of two students and control class used common discussion with each group consisting 4-5 students. Sunarto et al. (2008) found that discussion bounded students communication and interaction with their partners when sharing ideas or opinion.

In the discussion, the process can be seen the difference of students oral communication activities in experimental and control classes. Based on Table 2, students' oral communication skill in experimental class is better compared to control one, with an average grade of oral communication skills of students in experimental class is 78.33 and in control one, 67.15. This is because each group of the experimental class consists of only two students, so the discussion went more effectively and students oral communication skill trained well. $\mathrm{H}_{0}$ is rejected Based on the hypothesis of students oral communication skills through t-test for both classes with a significance level of 0.05 , and $\mathrm{p} 0.00$ which $0,00<0,05$. This shows that the average grade of students' oral communication skills between experimental and control classes is different. Therefore, it can be stated that there is a significant difference in students' oral communication skills in the experimental class, which applied the TPS learning model and in control class which applied common discussion learning.

Discussion with a paired partner made students freely to ask and speak up their opinion without feeling barrier, they would support the answers to each other, or seek new answers. Aziz et al. (2006) stated that in collaboration, students capacities become more empowered by faced social skills that lead them actively discovered concepts and communicated their thoughts with others. With only two members of each group, the collaboration between member become tighter. Therefore, students social skills increase, especially when communicating their thoughts to others. This is according to teachers' response that TPS learning model is beneficial to make students active, especially in their oral communication, because its membership only consists of two students, so each becomes more active in the learning process. It is different from control groups which each group include more than two members. The discussion went less effective because some students kept silent when the discussion was going. Not every student was able to participate in the classroom actively, some students inclined silent, they do not even try to analyze the problem and seek the answers with another member, yet some students not paid attention at all when the discussion was going.

In step of Pair, students learn to speak up their opinions, they found out and reanalyzed the data to solve the problems. This step gave students chances to share opinion or ideas and 
understand with their partner. This step made students help each other, appreciate friends' opinions, brave to speak up and defend their opinions, and also dared to ask and answer questions. This accordance to students statements as much as $92.1 \%$ students said that learning atmosphere of TPS learning model made them braver to speak up their opinion and as much as $97.4 \%$ students stated that learning with TPS learning model made them more courageous to ask and answer questions given by friends or teacher. This is also in line with Usman (2015) who stated that Think-Pair-Share learning improves students' speaking skills. In their courage to speak up their opinions, ask, and answer questions from friends and teacher could improve their oral communication skills, social interaction, and collaboration with other friends.

In the first meeting, the average grade of students' oral communication skill in the experimental class was 60.94. Oral communication activities such as asking, answering questions, speaking up an opinion, and responding to opinion had emerged, but students still felt shy. In the next meeting, skills had improved. They had more confidence and more open-minded to accept other's opinion and suggestion. Students were more active to asked, answer the questions to each other, and spoke up their opinion in the discussion. As much as $97.4 \%$ students said that they actively requested and responded to issues with their partner in discussion. The teacher also gave reasons that TPS learning model made students more active in learning, not only because most of them became engaged, but also because it was student-centered learning. The paired discussion gave students more chances to think, share an opinion without feeling shy and also answered questions to solve the problems.

Therefore all students became active in the learning process. Yulianti \& Fianti (2010) stated that collaboration to educate the students to run the communication in any directions. Discussion and presentation conducted by students made students learned to communicate their work results as well as asking and answering questions with friends and teacher, so that emerge new ideas. The implementation of TPS learning model made students became more enthusiastic in following the learning and discussion, they became more independent and understood better what they need to do, and build the confidence of students alone. Students felt a fun learning atmosphere. Therefore, the interaction between them improved. Students response supports this finding, $89.5 \%$ of students said that they were interested in following the subject of environmental change used TPS learning model and as much as $86.8 \%$ said they enjoyed the learning process by this model because they could discuss with friends during the learning. So the teachers stated that TPS learning model made students more enthusiastic in learning. As much as $2.6 \%$ of students were not interested in the learning with the TPS model, and $13.2 \%$ of students said that they did not enjoy the applied TPS learning model. This is because few students dislike discussion and presentation as their study style, they got bored and not suited their partner.

The strength of TPS learning model are 1) help students in the thinking process to construct their knowledge, 2) each student is prepared to collaborate, work together with their partner, collect ideas, and share opinion or solutions with the whole class, 3) improve oral communication skills of students because they have more time to discuss their ideas to each other. This model also has a weakness, which is too many groups as it needs more guide for every group in discussion. Also, it also requires better class management.

\section{CONCLUSSION}

Based on the analysis and discussion, it can be concluded that the TPS learning model has a positive influence on students' mastery skills and oral communication skills in the environmental change concept. Students' mastery skills in experimental and control class are different. The rise of the average score of post-test in the experimental class is higher than the control, and the classical passing grade in the experimental class is higher than the control one as well. Students' oral 
communication in experimental and control classes significantly different and average score of students' oral communication skills in experimental class is higher than control one.

\section{REFRENCES}

Abidin, Y. (2014). Desain Sistem Pembelajaran dalam Konteks Kurikulum 2013. Bandung: PT Refika Aditama.

Aziz, A., Yulianti, D. \& Handayani, L.(2006). Penerapan Model Pembelajaran Kooperatif dengan Memanfaatkan Alat Peraga Sains Fisika (Materi Tata Surya) untuk Meningkatkan Hasil Belajar dan Kerjasama Siswa. Jurnal Pendidikan Fisika Indonesia, 4(2): 94-99.

Azlina, N. (2008). Collaborative Teaching Environment System Using Think-Pair-Share Technique (Disertasi). Kuala Lumpur: University of Malaya.

Bamiro, A.O. (2015). Influences of Guided Discovery and Think-Pair-Share Strategies on Secondary School Students' Achievement in Chemistry. SAGE Open: 5(1):1-7.

Dirman \& Juarsih, C. (2014). Komunikasi dengan Peserta Didik. Jakarta: PT. Rineka Cipta.

Fiani, N., Jalmo, T \& Yolida, B. (2015). Pengaruh Penggunaan Model Think Pair Share (TPS) Terhadap Hasil Belajar Siswa. Jurnal Bioterdidik, 3(3): 1-9.

Giyastutik (2009). Penerapan Pembelajaran Kooperatif Think Pair Share untuk Meningkatkan Hasil Belajar Biologi Siswa Kelas VII A SMP Negeri 3 Karanganyar Tahun Pelajaran 2007/2008 (Skripsi). Surakarta: UNS.

Kamus Besar Bahasa Indonesia. On line at http://kbbi/pengetahuan.web.id. Diakses tanggal 17 Juli 2017. . On line at http://kbbi/penguasaan.web.id. Diakses tanggal 21 Oktober 2017.

Kitaoka, H. (2013). Teaching Methods that Help Economics Students to be Effective Problem Solvers. International Journal of Arts and Commerce, 2(1): 101-110.

Krathwohl, D.R. (2002). A Revision of Bloom's Taxonomy: An Overview. Theory into Practice, 41(4): 212-218.

Kusuma, A.S. \& Aisyah, M.N. (2012). Implementasi Model Pembelajaran Kooperatif Tipe TPS untuk Meningkatkan Aktivitas Belajar Akuntansi Siswa Kelas XII IPS SMA Negeri 2 Wonosari Tahun Ajaran 2011/2012. Jurnal Pendidikan Akuntansi Indonesia, 10(2): 43-63.

Marlina, H. \& Ikhsan, M. (2014). Penggunaan Model Pembelajaran Kooperatif Tipe Think-Pair-Share (TPS) untuk Meningkatkan Kemampuan Komunikasi dan Disposisi Matematis Siswa di SMA Negeri 1 Bireuen. Jurnal Didaktik Matematika, 1(1): 83:95.

Ni'mah, D. \& Dwijanti, P. (2014). Penerapan Model Pembelajaran Think-Pair-Share (TPS) dengan Metode Eksperimen untuk Meningkatkan Hasil Belajar dan Aktivitas Belajar Siswa Kelas VII MTs Nahdatul Muslimin Kudus. Unnes Physics Education Journal, 3(2): 18-25.

Oktavia, R., Mustikaningtyas, D. \& Mubarok, I. (2016). Pengaruh Model Think-Pair-Share (TPS) Terintegrasi Mind Mapping terhadap Kreativitas dan Hasil Belajar Siswa. Unnes Journal of Biology Education, 5 (2): 154-162.

Rahayu, E.L. (2013). Penggunaan Media Presentasi Powerpoint untuk Meningkatkan Keterampilan Berkomunikasi Belajar IPS pada Siswa Kelas VII A SMP Negeri 4 Kalasan Tahun Ajaran 2012/2013 (Skripsi). Yogyakarta: Universitas Negeri Yogyakarta.

Rahayu, A. \& Pramukantoro, J.A. (2013). Pengaruh Model Pembelajaran Think-Pair-Share dengan Strategi Index Card Match terhadap Hasil Belajar Siswa pada Standar Kompetensi Menerapkan Dasar-dasar Elektronika Di SMK Negeri 1 Madiun. Jurnal Pendidikan Teknik Elektro, 2(3): 991-999.

Rumini, S. \& Sundari, S.(2006). Psikologi Pendidikan. Yogyakarta: UNY Press.

Rusmaryanti, D. (2013). Meningkatkan Hasil Belajar Biologi dengan Model Pembelajaran Kooperatif Tipe TPS (Think Pair Share) pada Siswa kelas VIIIA MTs Al Huda 2 Jenawi Karanganyar Tahun Pelajaran 2012/2013. Jurnal Pendidikan 22(3): 285-308.

Sunarto, W., Sumarni, W., \& Suci, E.(2008). Hasil Belajar Kimia Siswa dengan Model Pembelajaran Metode Think-Pair-Share dan Metode Ekspositori. Jurnal Inovasi Pendidikan Kimia, 2(1): 244-249.

Tamwil, M., \& Liliasari (2014). Keterampilan-keterampilan Sains dan Implementasinya dalam Pembelajaran IPA. Makassar: UNM Press.

Usman. A.H. (2015). Using the Think-Pair-Share Strategy to Improve Students' Speaking Ability at Stain Ternate. Journal of Education and Practice, 6(10): 37-45.

Whitehead. D.W. (2007). Research-based Criteria for the Design and Selection of Literacy and Thinking Tools. Literacy Learning: The Middle Years Journal, 1(15).

Winarni, E., Dewi, N.K., \& Martuti, N.K.T. (2015). Penerapan Model Think Pair Share dengan Pendekatan Guided Inquiry Learning pada Materi Pengelolaan Lingkungan. Unnes Journal of Biology Education, 4 (3): $262-268$.

Yulianti, D. \& Fianti (2010). Penerapan Model Bermain Berbasis Kontekstual untuk Meningkatkan Minat Sains Siswa Sekolah Dasar. Lembaran Ilmu Kependidikan, 39(2): 48-53.

Yusefni, W. \& Sriyati, S. (2015). Analisis Hubungan Aktivitas Writing to Learn dengan Kemampuan Berkomunikasi Lisan Siswa dalam Pembelajaran Science Writing Heuristic dalam: Prosiding Simposium Nasional Inovasi dan Pembelajaran Sains 2015 (SNIPS 2015): 585-588. Bandung: Indonesian University of Education Press. 